\title{
Comparative pathogenesis of three strains of infectious hematopoietic necrosis virus in rainbow trout Oncorhynchus mykiss
}

\author{
S. E. LaPatra ${ }^{1, *}$, J. M. Groff ${ }^{2}$, J. L. Fryer ${ }^{3}$, R. P. Hedrick ${ }^{2}$ \\ ${ }^{1}$ Oregon Department of Fish and Wildlife, Department of Microbiology, Oregon State University, Corvallis, \\ Oregon 97331-3804, USA \\ ${ }^{2}$ Aquaculture and Fisheries Program, Department of Medicine, School of Veterinary Medicine, University of California, Davis, \\ California 95616, USA \\ ${ }^{3}$ Department of Microbiology, Oregon State University, Corvallis, Oregon 97331-3804, USA
}

\begin{abstract}
Three strains of infectious hematopoietic necrosis virus (IHNV) were compared for their pathogenicity to alevin rainbow trout Oncorhynchus mykiss by waterborne exposure of the trout to approximately equal concentrations of each virus strain. The Idaho strain of IHNV (Type 2) was the most virulent and induced a $62 \%$ mortality over a $10 \mathrm{~d}$ period at water temperatures of $10^{\circ} \mathrm{C}$. In contrast, strains of IHNV from Oregon (Type 1) and California (Type 3) caused only 4 and $6 \%$ mortality, respectively, among rainbow trout infected under the same conditions. Histopathological signs of infection (hematopoietic necrosis) were first detected 3 to $4 \mathrm{~d}$ following exposure to virus. In trout exposed to the Idaho strain of IHNV, lesions were severe and progressive. The Oregon and California strains of the virus induced similar changes in the kidney, spleen, and pancreas but these were less severe, and by 8 to $10 \mathrm{~d}$ following exposure had resolved in most of the fish. These results showed the Type 2 strain to be the most pathogenic for rainbow trout.
\end{abstract}

\section{INTRODUCTION}

Infectious hematopoietic necrosis virus (IHNV) is a rhabdovirus of economic importance as a pathogen of salmon and trout. Once confined to the Pacific Northwest of North America, the virus is now enzootic in Japan and it has also been observed in the eastern United States (Wolf 1988), Taiwan (Chen et al. 1985), and recently in Italy (Bovo et al. 1987) and France (Hattenberger-Baudouy \& de Kinkelin 1988). This virus is responsible for substantial yearly losses of young fish at hatcheries in North America (Busch 1983, Groberg \& Fryer 1983).

Infectious hematopoietic necrosis (IHN) is primarily a disease of sockeye (kokanee) Oncorhynchus nerka and chinook $O$. tshawytscha salmon and rainbow (steelhead) trout $O$. mykiss. Initial comparisons of virus isolants obtained from naturally-infected sockeye and chinook salmon and from rainbow trout showed the isolants had similar morphology and induced identical

\footnotetext{
- Addressee for correspondence
}

signs of disease in the above 3 hosts (Amend \& Chambers 1970). Microscopic signs of disease in infected fish are characterized by necrosis of the hematopoietic tissues in the kidney and spleen, and necrosis of endocrine and exocrine pancreas (Amend et al. 1969). Signs of the disease in chinook salmon are similar to those in infected sockeye salmon and rainbow trout, and the virus is cytotropic for, but not confined to, hematopoietic tissue (Yasutake et al. 1965).

In their review of the literature, Pilcher \& Fryer (1980) concluded that virus isolants from sockeye and chinook salmon and rainbow trout may exhibit different degrees of virulence. Initial attempts at distinguishing strains of IHNV by serological studies showed some differences, but failed to identify distinct serotypes (McCain et al. 1971). Recent studies have shown differences in the molecular weights of virion structural proteins (Leong et al. 1981) and have allowed the separation of 71 isolants into 5 types (Hsu et al. 1986). Winton et al. (1988) used 3 monoclonal antibodies and were able to separate 12 IHNV isolants into 4 groups. In this study the virulence and pathogenesis of 3 of the 
most commonly encountered strains (Types 1,2 and 3) of IHNV are compared in rainbow trout.

\section{MATERIALS AND METHODS}

Cell lines. The fish cell-lines used for the isolation, propagation, and identification of the virus isolants were the CHSE-214 line (ATCC CRL 1681) from chinook salmon (Lannan et al. 1984) and the EPC line from common carp Cyprinus carpio (Fijan et al. 1983). Both lines were grown in Eagle's minimum essential medium (MEM, GIBCO Laboratories, Grand Island, NY, USA) supplemented with fetal bovine serum (FBS, Hyrlone Laboratories, Ogden, UT, USA) to $10 \%$ (MEM-10), L-glutamine to $10 \mathrm{mM}$, penicillin to $50 \mathrm{IU} \mathrm{ml} \mathrm{m}^{-1}$, streptomycin to $50 \mu \mathrm{g} \mathrm{ml} \mathrm{m}^{-1}$, and buffered with $7.5 \%$ sodium bicarbonate or $0.15 \mathrm{mM}$ Hepes (all from $\mathrm{GIBCO}$ ). For routine cell propagation, the CHSE-214 line was incubated at $20^{\circ} \mathrm{C}$ and the EPC line at $25^{\circ} \mathrm{C}$

Viruses. Viruses used in this study included a 1983 isolant of IHNV from steelhead trout at Round Butte Hatchery (Deschutes River, OR, USA), a 1983 isolant from rainbow trout at the Aquaculture Research Center (Hagerman Valley, ID, USA), and a 1984 isolant obtained from chinook salmon at Trinity River Hatchery (Trinity River, CA, USA). The viruses obtained from rainbow and steelhead trout were from mortalities that occurred during epizootics. The virus from chinook was from a carrier adult, but the same strain has been associated with epizootics in juvenile chinook at the Trinity River Hatchery (Hsu et al. 1986). All of the viruses were isolated and identified by standard methods (Amos 1985). Each isolant was passed 2 additional times in CHSE- 214 cells at $16^{\circ} \mathrm{C}$ in MEM-5 to prepare stocks for artificial infections and electrophoretic comparisons. They were then stored at $-70^{\circ} \mathrm{C}$.

To determine the electropherotype of the Oregon, Idaho, and California IHNV isolants, electrophoretic patterns of the structural polypeptides were compared. Virus purification was performed as described by Leong et al. (1981). Sodium dodecylsulfate polyacrylamide gel electrophoresis (SDS-PAGE) conditions were similar to those of Lammeli (1970). Purified virus was mixed $1: 1$ in $2 \times$ concentrated sample buffer $(120 \mathrm{mM}$ tris base, $4 \% \mathrm{w} / \mathrm{v}$ SDS, $10 \% \mathrm{w} / \mathrm{v} 2$-mercaptoethanol, $20 \% \mathrm{v} / \mathrm{v}$ glycerol, and $3 \mathrm{mM}$ bromophenol blue), and placed in a boiling water bath for 1 to $2 \mathrm{~min}$. Polypeptides were separated by electrophoresis using a $12 \%$ separating gel and a $4.5 \%$ stacking gel, for 6 to $7 \mathrm{~h}$ at $12 \mathrm{~mA}$. Standard molecular weight marker proteins (Bio-Rad Laboratories, Richmond, CA, USA) were prepared as described by the manufacturer and included phosphorylase $b$ (94000), bovine serum albumin $(68000)$, ovalbumin $(43000)$, carbonic anhydrase $(30000)$, soybean trypsin inhibitor $(21000)$, and lysozyme (14000). After electrophoresis, the polypeptides were stained using silver nitrate as described by Merril et al. (1981). A Type 1 IHNV from kokanee salmon (Metolius River, OR, USA) previously described by Hsu et al. (1986), was also used in the electrophoretic comparison.

Experimental fish. Rainbow trout, $2.8 \mathrm{~g}$ mean weight and 6 to 8 mo old, were provided by Mt Lassen Trout Farms (Red Bluff, CA, USA). Fish were held at the University of California, Davis, Fish Disease Laboratory, in $10^{\circ} \mathrm{C}$ fish-pathogen-free well water where all experiments were conducted. Fish were fed a dry pelleted diet (Silver Cup, Murray, UT, USA) twice daily.

Artificial infections. Viral infections were induced in rainbow trout by exposing fish to between $10^{5.5}$ and $10^{6.0}$ plaque forming units (PFU) $\mathrm{ml}^{-1}$ of each of the 3 strains in replicate aquaria containing $2 \mathrm{l}$ of well water. Fifty fish were placed in each aquaria containing virus and into 2 control aquaria containing cell-culture fluid without virus. After a $12 \mathrm{~h}$ exposure with aeration at $10^{\circ} \mathrm{C}$, the water flow was resumed at a rate of approximately $0.21 \mathrm{~min}^{-1}$

Histology. Five fish were removed on each of 10 consecutive days beginning immediately following exposure from one replicate of each virus-exposed group and one mock-infected (control) group. Fish were euthanized, their abdomens opened and placed in Bouin's solution for approximately $25 \mathrm{~d}$. Midline saggital sections from paraffin-embedded whole fish were stained with hematoxylin and eosin (H \& E) using standard histological methods (Humason 1979).

Detection of virus after artificial infection. The second replicate of each virus-exposed group and mockinfected control was monitored for mortality. Dead fish were removed daily, weighed, and examined for virus by standard methods (Amos 1985). Virus concentrations used in fish exposures or isolated from dead fish were determined by plaque assay procedures similar to those described by Burke \& Mulcahy (1980) using EPC cells incubated at $15^{\circ} \mathrm{C}$ for $10 \mathrm{~d}$.

\section{RESULTS}

\section{Viral proteins}

Electrophoretic profiles of the 3 virus isolants used to infect fish showed differences in the structural proteins (Fig. 1). Comparison of the relative mobilities of the nucleocapsid ( $\mathrm{N}$-)protein indicated that the 3 isolants were different for this virion polypeptide. The molecular weight of the $\mathrm{N}$-protein was the smallest for both 
Fig. 1. Electrophoretic profile of different isolants of infectious hematopoietic necrosis virus (IHNV) used. The 5 structural proteins of IHNV are designated $\mathrm{L}$ (polymerase), G (envelope glycoprotein), $\mathrm{N}$ (nucleocapsid protein), and $\mathrm{M} 1$ and M2 (matrix proteins). Lane representations are (1) molecular weight standards; (2) isolant from steelhead trout Oncorhynchus mykiss at Round Butte Hatchery (Deschutes River, OR, USA); (3) isolant from rainbow trout $O$. mykiss at Aquaculture Research Center (Hagerman Valley, ID, USA); (4) isolant from chinook salmon $O$. tshawytscha at Trinity River Hatchery (Trinity River, CA, USA); (5) isolant from kokanee salmon $O$. nerka (Metolius River, OR, USA); (6) molecular weight standards which range from 94 to $21 \mathrm{KD}$

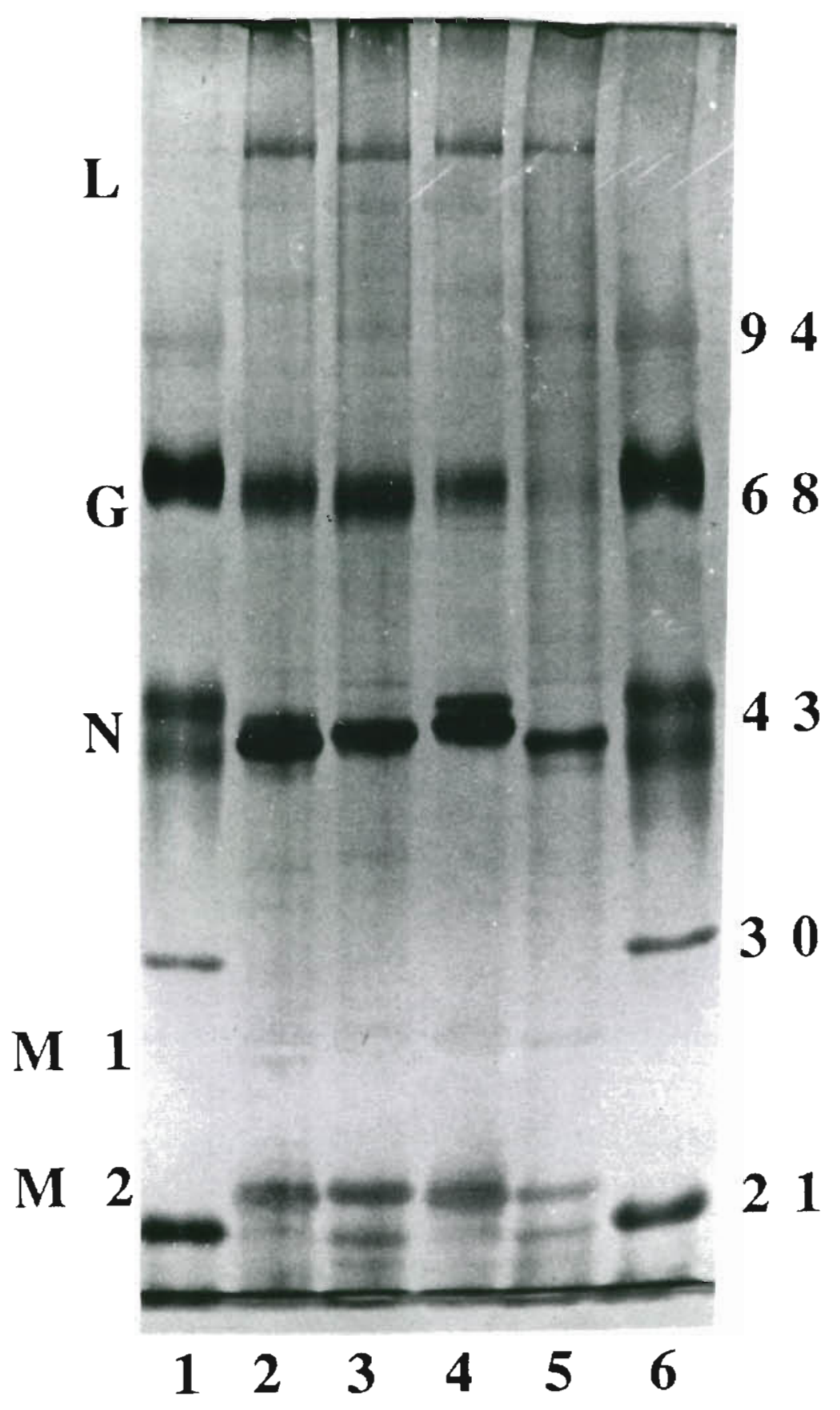

Oregon isolants (Lanes 2 and 5), greater for the Idaho isolant (Lane 3) and greatest for the California isolant (Lane 4). Based on these N-protein size determinations and consistent with the typing scheme proposed by Hsu et al. (1986), both Oregon isolants were Type 1 IHNV, the Idaho isolant a Type 2, and the California isolant a Type 3.

\section{Histological comparison}

Control fish

Tissues from fish examined at 1,7 and $10 \mathrm{~d}$ postexposure showed no marked changes although slight depletions of hematopoietic tissue from the anterior 
and posterior kidney were detected. The spleen, liver, pancreas, skin, heart, and gills had no detectable pathological changes.

Fish infected with Oregon isolant

Necrotic cells in the hematopoietic tissue of the anterior and posterior kidney were observed in 1/5 fish on Days 3 and 4 . The extent of necrosis increased in the kidney and spleen in 3/5 fish by Days 5 and 6 . There was a severe multifocal to diffuse necrosis in $4 / 5 \mathrm{fish}$ on Day 7 . Pancreatic necrosis in $1 / 5$ fish was also observed on Day 7 but the liver and pancreas of all fish were not severely affected. On Days 8 to 10 , there was resolution of the lesions, and only isolated necrotic cells occurred in most fish. On Day 10, 1/5 fish had severe necrosis of the kidney, spleen, and ventricle of the heart.

\section{Fish infected with Idaho isolant}

There were no changes detected until $4 \mathrm{~d}$ postexposure. Isolated necrotic cells were present in the hematopoietic tissue of the anterior and posterior kidney in $2 / 5$ fish. There was multifocal necrosis of renal hematopoietic tissue in $5 / 5$ fish on Day 5. By Day 6 , there was diffuse necrosis with hemorrhages in the anterior (Fig. 2A, B) and posterior kidney. The posterior kidney also had tubular changes including degeneration of the tubular epithelium (Fig. 2C, D). The spleen showed similar pathology including loss of ellipsoids (Fig. 2E, F) in $3 / 5$ fish, and there was also multifocal necrosis in the pancreas of $1 / 5$ fish. Multifocal hepatic necrosis with hepatocytes exhibiting margination of chromatin and the thickened nuclear membranes (Fig. $3 \mathrm{~A}, \mathrm{~B})$ occurred in $1 / 5$ fish on Day 7. There was also a diffuse and moderate to severe necrosis of the hematopoietic cells in the anterior and posterior kidneys and spleens of all fish on Day 7 . The pancreas of $3 / 5$ fish also showed similar necrotic changes including degeneration and necrosis of the exocrine and endocrine tissues on Day 7 (Fig. 3C, D). Necrosis became progressively more severe on Days 8 to 10 in the anterior and posterior kidney and pancreas. Edema was also evident in these fish.

\section{Fish infected with California isolant}

The first significant changes were observed on Day 5 and consisted of random necrotic cells in the hematopoietic tissue of the anterior kidney in $1 / 5$ fish and mild necrosis in the pancreas of $2 / 5$ fish. On Day 6 , $4 / 5$ fish had moderate necrosis of the hematopoietic tissues of the anterior and posterior kidney and spleen. There was also hepatic necrosis in $1 / 5$ fish. By Day 7 , the extent of necrosis decreased and $2 / 5$ fish had a moderate necrosis of the hematopoietic cells of the kidney and spleen. On Days 8 to 10 , residual small areas of necrosis surrounded by macrophages containing necrotic debris were common. By Day 10, few necrotic cells were found and all lesions were resolved in the 5 fish examined

Detection of virus after artificial infection

Cumulative percent mortality $10 \mathrm{~d}$ post-exposure was $4(2.150) 62(31 / .50)$, and $6 \%(3 / 50)$ in rainbow trout infected with the Oregon, Idaho, and California isolants of IHNV, respectively. When the experiment was terminated ( $21 \mathrm{~d}$ ), mortality was 14,86 , and $14 \%$ for the Oregon, Idaho, and California IHNV isolants, respectively (Table 1). Virus was isolated from all dead fish and virus concentrations in 16 randomly selected dead fish ranged from $10^{5.3}$ to $10^{6.7} \mathrm{PFU} \mathrm{g} \mathrm{g}^{-1}$ viscera.

\section{DISCUSSION}

Previous studies have shown that IHNV is cytotropic for hematopoietic tissue of the kidney but the spleen, liver, pancreas, and granular cells of the stomach may also exhibit degenerative changes (Wood \& Yasutake 1956). Yasutake \& Amend (1972) described the histopathogenesis of IHN in sockeye salmon artificially infected with one isolant of IHNV. The present study compared the histopathogenesis of 3 electropherotypes of IHNV in rainbow trout and correlated histological changes with virus-induced mortality.

Microscopic pathology induced by the Oregon and California isolants, Types 1 and 3 IHNV strains, appeared the same but was less severe and involved

Table 1. Oncorhynchus mykiss. Cumulative percent mortality in rainbow trout $(\mathrm{n}=50$ ) after artificial infection with 3 isolants of infectious hematopoietic necrosis virus (IHNV). Type 1 Oregon isolant from steelhead trout $O$. mykiss at Round Butte Hatchery (Deschutes River, OR, USA). Type 2 Idaho isolant from rainbow trout O. mykiss at Aquaculture Research Center (Hagerman Valley, ID, USA). Type 3 California isolant from chinook salmon $O$. tshawytscha at Trinity River Hatchery (Trinity River, CA, USA)

\begin{tabular}{lccc}
\hline IHNV strain & $\begin{array}{c}\text { Exposure conc. } \\
\text { (PFU m! }\end{array}$ & \multicolumn{2}{c}{ Post-infection (d) } \\
\hline Oregon & $8.3 \times 10^{5}$ & 4 & 21 \\
Idaho & $3.1 \times 10^{5}$ & 62 & 86 \\
California & $9.8 \times 10^{5}$ & 6 & 14 \\
\hline
\end{tabular}




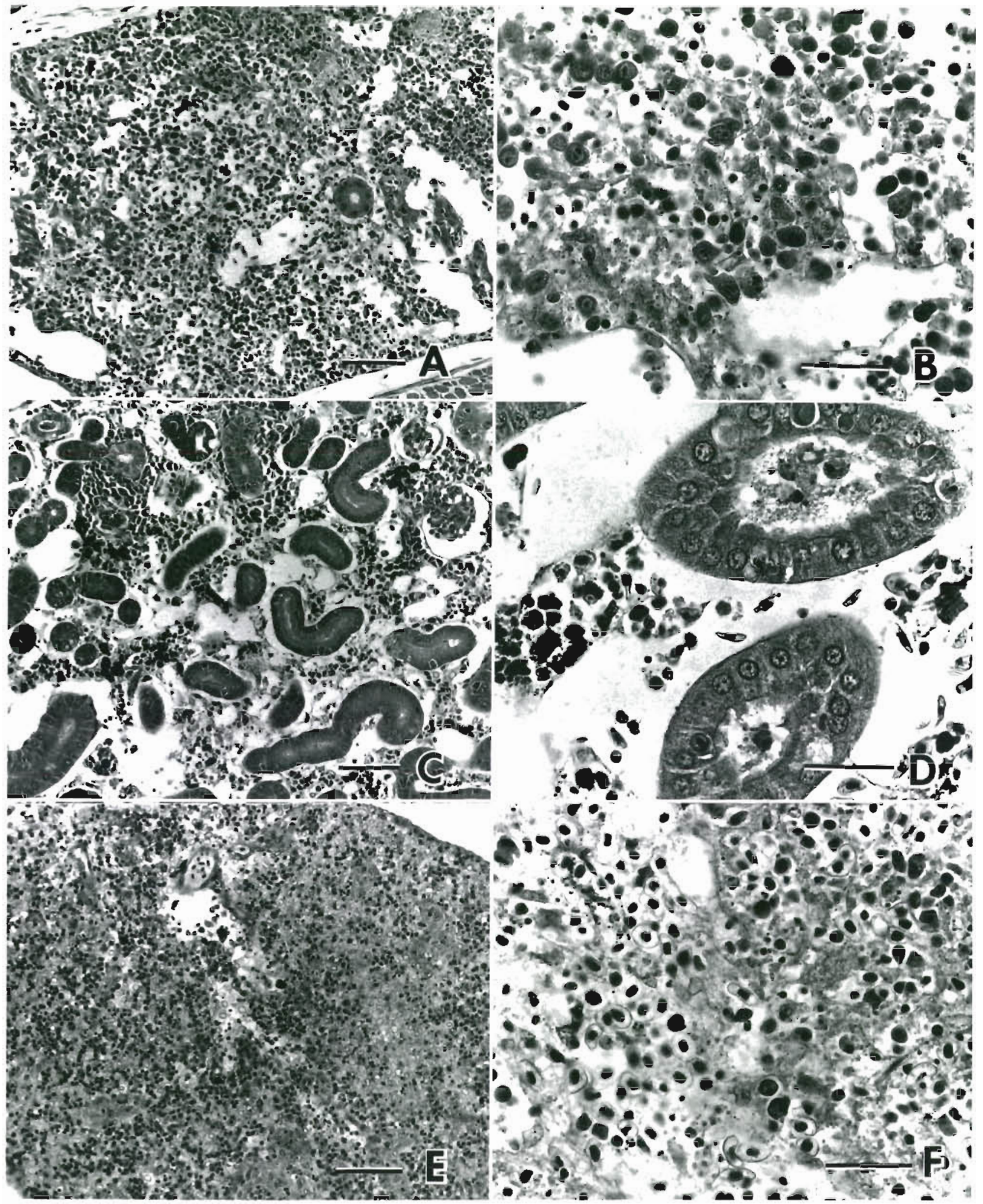

Fig. 2. Oncorhynchus mykiss. Histological sections of rainbow trout infected with Type 2 infectious hematopoietic necrosis virus from Idaho, USA. (A, B) Affected hematopoietic tissue in the anterior kidney; (C, D) affected hematopoietic tissue and proximal tubules in the posterior kidney; $(E, F)$ spleen. Hematoxylin and eosin stain. Scale bar $=20 \mu \mathrm{m}$ 


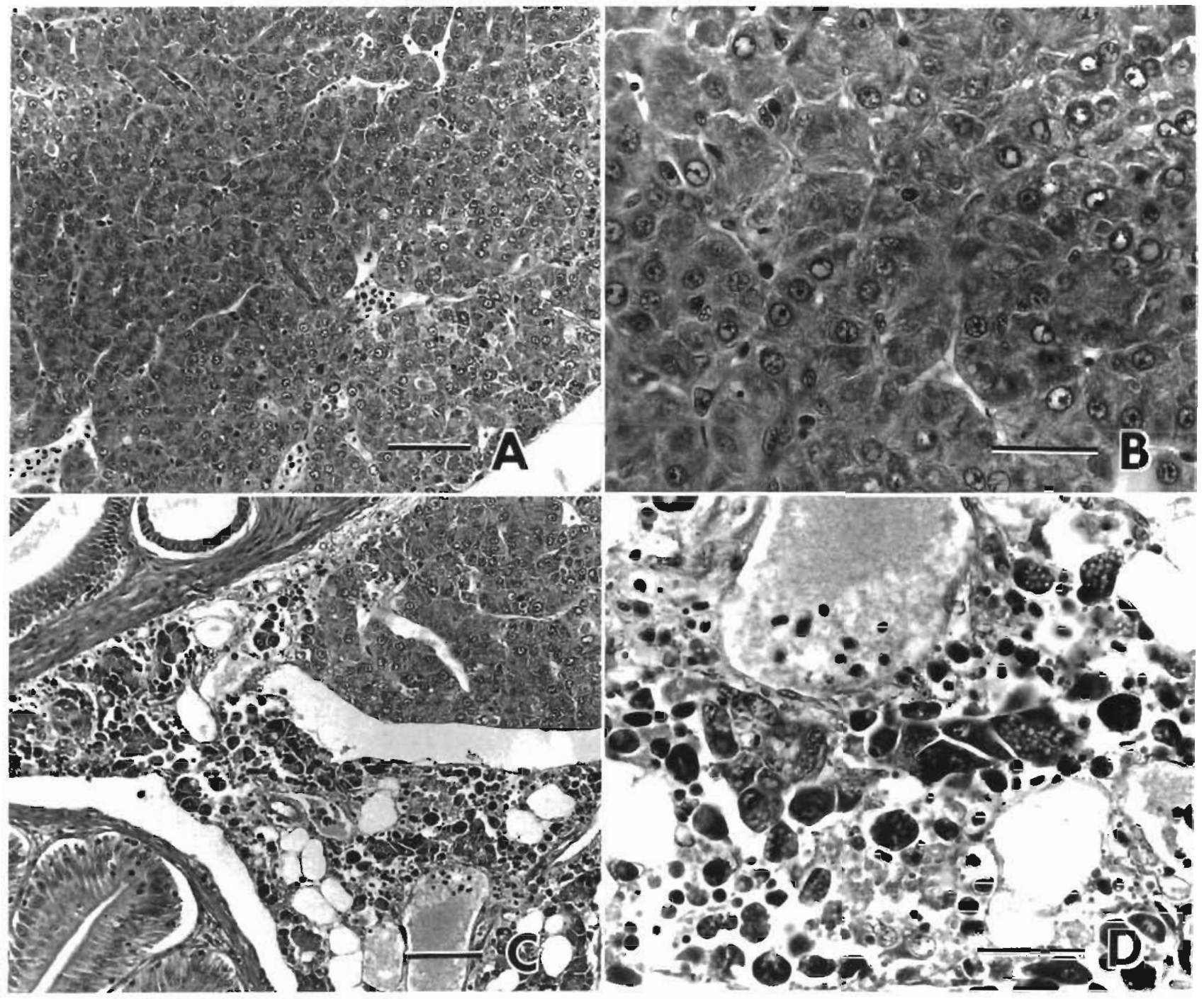

Fig. 3. Oncorhynchus mykiss. Histological section of affected tissues in rainbow trout infected with Type 2 infectious hematopoietic necrosis virus from Idaho, USA. (A, B) Liver; (C, D) pancreas. Hematoxylin and eosin stain. Scale bar $=20 \mu \mathrm{m}$

fewer tissue types in rainbow trout than the Type 2 IHNV from Idaho. Histological changes in rainbow trout infected with Type 2 IHNV began $4 \mathrm{~d}$ postinfection in the hematopoietic tissue of kidney, with further involvement of spleen, liver, and pancreatic tissues. These observations are in agreement with results of earlier studies, but eosinophilic granular cells of the lamina propria, described by Yasutake \& Amend (1972), were absent. Detection of eosinophilic granular cells may be dependent on chemical fixation and staining procedures, and age of the fish. Fish used in this study were 6 to 8 mo old and it has been reported that no granular cell involvement was observed in 7 to 14 mo old sockeye salmon (Yasutake 1978).

Virus-induced mortality was correlated with the severity of the histological lesions observed. The Type
2 strain was more virulent and caused more severe lesions than Type 1 and 3 strains in rainbow trout. LaPatra et al. (1990) have shown that there are strains of IHNV that exhibit differences in virulence for different species of salmonids. A Type 2 strain from Idaho was shown to be more virulent for rainbow trout and a Type 1 strain from Oregon was more virulent for kokanee salmon. A Type 3 strain from California has also been shown to be more virulent for chinook salmon (LaPatra 1989). This study supports those results and shows histologically that the Type 2 IHNV' strain is more pathogenic for rainbow trout.

Recent studies have shown that different IHNV isolants can be grouped by antigenic, biochemical, and virulence characteristics and that not all IHNV isolants are the same (Hsu et al. 1986, Winton et al. 1988 , LaPatra 1989, LaPatra et al. 1990). Serological compari- 
sons of IHNV isolants using monoclonal antibodies directed against the glycoprotein (G) tended to group isolants more by geographic location rather than virulence (Winton et al. 1988). For other rhabdoviruses such as rabies, it has been shown with G-specific monoclonal antibodies that pathogenicity is dependent on the presence of an antigenic determinant on the Gprotein (Dietzschold et al. 1983). This study demonstrates a correlation between virulence and electrophoretic mobility of the $\mathrm{N}$-protein of different IHNV isolants. Possibly, the use of monoclonal antibodies directed against the $\mathrm{N}$-protein of different electropherotypes of IHNV would allow serological separation of IHNV isolants that correlated more with virulence. These monoclonals might also provide a means to identify factors involved in the regulation of IHNV pathogenicity.

Acknowledgements. The authors thank W. Groberg (Oregon Department of Fish and Wildlife), N. Wood (Aquaculture Research Center, Hagerman Valley, Idaho), and W. Wingfield (California Department of Fish and Game) for providing isolants of IHNV, the Mt Lassen Trout Farm for supplying the fish, and C. Pelroy and T. Curry for typing the manuscript. We also thank T. McDowell for assistance during the course of the study. This work was sponsored in part by Oregon Sea Grant. Dingell-Johnson/Wallop-Breaux Federal Aid in Sport Fish Restoration Funds provided by California Department of Fish and Game, and a Tarter Fellowship. Oregon Agricultural Experiment Station Technical Paper No. 8846.

\section{LITERATURE CITED}

Amend, D. E., Chambers, V C. (1970). Morphology of certain viruses of salmonid fishes. I. In vitro studies of some viruses causing hematopoietic necrosis. J. Fish. Res. Bd Can. 27. 1285-1293

Amend, D. F., Yasutake, W T., Mead, R. W (1969). A hematopoietic virus disease of rainbow trout and sockeye salmon. Trans. Am. Fish. Soc. 98: 796-804

Amos, K. H. (1985). Procedures for the detection and identification of certain fish pathogens, 3rd edn. Fish Health Section, American Fisheries Society, Corvallis, Oregon, p. 6-21

Bovo, G., Giorgetti, G., Jorgensen, P. E. V., Olesen, N. J. (1987). Infectious hematopoietic necrosis: first detection in Italy. Bull. Eur. Ass. Fish Pathol. 7: 124

Burke, J. A., Mulcahy, D. (1980). Plaquing procedure for infectious hematopoietic necrosis virus. Appl. environ. Microbiol. 39: 872-876

Busch, R. A. (1983). Viral disease and considerations in the commercial trout industry in Idaho. In: Leong, J. C., Barila, T Y (eds.). Workshop on viral diseases of salmonid fishes in the Columbia River Basin, 7-8 October 1982, Portland, Oregon. Special Publication, Bonneville Power Administration, p. $84-100$

Chen, S. N., Kou, G. H., Hedrick, R. P., Fryer, J. L. (1985). The occurrence of viral infection of fish in Taiwan. In: Ellis, A. E. (ed.), Fish and shellfish pathology. Academic Press, Inc., New York

Dietzschold, B., Wunner, W. H., Wikto, T. J., Lopes, D., Lafon,
M., Smith, C. L., Koprowski, H. (1983). Characterization of an antigenic determinant of the glycoprotein that correlates with pathogenicity of rabies virus. Proc. Natn Acad. Sci. U.S.A. 80: $70-74$

Fijan, N., Sulimanovic, D., Bearzotti, M., Muzinie, D., Zwillenberg, L. D., Chilmonczyk, S., Vantherot, J. F., de Kinkelin, P. (1983). Some properties of the Epithelioma papulosum Cyprini (EPC) cell line from carp Cyprinus carpio. Ann. Virol. (Inst. Pasteur) 134E: 207-220

Groberg. W J., Fryer, J. L. (1983). Increased occurrences of infectious hematopoietic necrosis virus in fish at Columbia River basin hatcheries: 1980-1982. Publication of the Sea Grant College Program, Oregon State University, Corvallis, Oregon. Oregon Agricultural Experiment Station Technical Paper No. 6620

Hattenberger-Baudouy, A. M., de Kinkelin, P. (1988). Serological evidence for infectious hematopoietic necrosis in rainbow trout from an outbreak in France. Abstract: International Fish Health Conference, Vancouver, B. C., July 19-20, p. 6.

Hsu, Y L.,Engelking, H. M., Leong, J. C. (1986). Occurrence of different types of infectious hematopoietic necrosis virus in fish. Appl environ. Microbiol. 52: 1353-1361

Humason, G. L. (1979). Animal Tissue Techniques. W H. Freeman Co., San Francisco

LaPatra, S. E. (1989). Strain differentiation and detection of infectious hematopoietic necrosis virus. Doctoral dissertation. Oregon State University, Corvallis

LaPatra, S. E., Groberg, W J., Rohovec, J. S., Fryer, J. L. (1990). Size and susceptibility of two salmonid species to two strains of infectious hematopoietic necrosis virus. Trans. Am. Fish. Soc. (in press)

Lammeli, U. K. (1970). Cleavage of structural proteins during the assembly of the head of bacteriophage T4. Nature (Lond.) 227: 680-685

Lannan, C. N., Winton, J. R., Fryer, J. L. (1984). Fish cell lines: establishment and characterization of nine cell lines from salmonids. In Vitro 20 (9): 671-676

Leong, J. C., Hsu, Y L., Engelking, H. M., Mulcahy, D. (1981). Strains of infectious hematopoietic necrosis (IHN) virus may be identified by structural protein differences. In: Anderson, D. P., Hennessen, W. (eds.) International symposium of fish biologics: serodiagnostics and vaccines. Dev. biol. Stand. 49: 43-55

McCain, B. B., Fryer, J. L., Pilcher, K. S. (1971). Antigenic relationships in a group of three viruses of salmonid fish by cross neutralization. Proc. Soc. exp. Biol. Med. 146: $630-634$

Merril, C. R., Goldman, D., Sedman, S. A., Ebert, H. M. (1981) Ultrasensitive stain for proteins in polyacrylamide gels shows regional variation in cerebrospinal fluid proteins. Science 211: 143-144

Pilcher, K. S., Fryer, J. L. (1980). The viral diseases of fish: a review through 1978. CRC critical Rev. Microbiol. 7: $287-364$

Winton, J. R., Arakawa, C. K., Lannan, C. N., Fryer, J. L. (1988). Neutralizing monoclonal antibodies recognize antigenic variants among isolates of infectious hematopoietic necrosis virus. Dis. aquat. Org. 4: 199-204

Wolf, K. (1988). Fish Viruses and Fish Viral Diseases. Cornell University Press, Ithaca, New York, p. 83-114

Wood, E. M., Yasutake, W T (1956). Histopathologic changes of a virus-like disease of sockeye salmon. Trans. Am. microsc. Soc. 75: 85-90

Yasutake, W. T. (1970). Comparative histopathology of epizootic salmonid virus diseases. In: Snieszko, S. F. (ed.) A symposium on diseases of fish and shellfishes. Special 
Publication No. 5, Anerican Fisheries Society, Washington, D.C., p. $341-350$

Yasutake, W. T. (1978). Histopathology of yearling sockeye salmon (Oncorhynchus nerka) infected with infectious hematopoietic necrosis (IHN). Fish Pathol. 14: 59-64

Yasutake, W. T., Amend, D. F. (1972). Some aspects of

Responsible Subject Editor: Dr T Evelyn, Nanaimo, B. C., Canada pathogenesis of infectious hematopoietic necrosis (IHN). J. Fish Biol. 4: 261-264

Yasutake, W. T., Parisot, T J., Klontz, G. W. (1965). Virus diseases of salmonidae in western United States. II. Aspects of pathogenesis. Ann. N.Y Acad. Sci. 126: $520-530$

Manuscript first received: May 4, 1989

Revised version accepted: March 26, 1990 